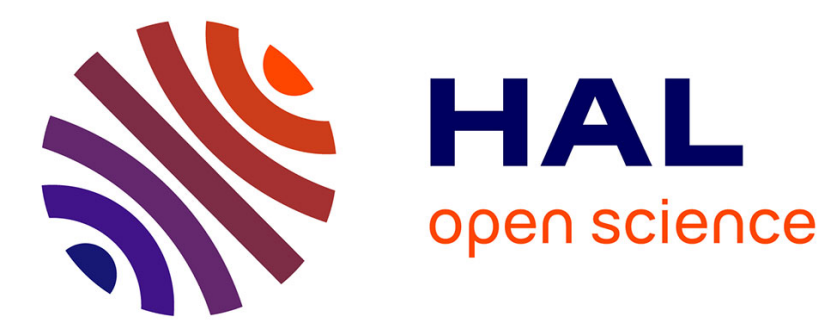

\title{
A scientific note on new insights in the pollination of guarana (Paullinia cupana var. sorbilis)
}

Cristiane Krug, Marcos Vinicius Bastos Garcia, Flávia Batista Gomes

\section{To cite this version:}

Cristiane Krug, Marcos Vinicius Bastos Garcia, Flávia Batista Gomes. A scientific note on new insights in the pollination of guarana (Paullinia cupana var. sorbilis). Apidologie, 2015, 46 (2), pp.164-166. 10.1007/s13592-014-0304-3 . hal-01284430

\section{HAL Id: hal-01284430 \\ https://hal.science/hal-01284430}

Submitted on 7 Mar 2016

HAL is a multi-disciplinary open access archive for the deposit and dissemination of scientific research documents, whether they are published or not. The documents may come from teaching and research institutions in France or abroad, or from public or private research centers.
L'archive ouverte pluridisciplinaire HAL, est destinée au dépôt et à la diffusion de documents scientifiques de niveau recherche, publiés ou non, émanant des établissements d'enseignement et de recherche français ou étrangers, des laboratoires publics ou privés. 


\title{
A scientific note on new insights in the pollination of guarana (Paullinia cupana var. sorbilis)
}

\author{
Cristiane Krug, Marcos Vinicius Bastos Garcia, Flávia Batista Gomes \\ Entomology Laboratory-Embrapa Western Amazon, Rodovia AM-010, Km 29, Zona Rural, C.P. 319, 69010-970, \\ Manaus, Amazonas, Brazil
}

Received 12 February 2014 - Revised 20 May 2014 - Accepted 25 June 2014

Guarana (Paullinia cupana var. sorbilis (Mart.) Ducke, Sapindaceae family) is an important and traditional crop of significant economic and social importance in the Amazon region. It is a Brazilian native plant, cultivated by large- and small-scale producers (Embrapa 2005). Its fruits are dehiscent capsules that contain one or three dark brown seeds, with 2.3 to $5 \%$ caffeine. The seeds need to be processed to obtain the powder, syrup, or extract (Angelo et al. 2008), which is used in food, beverage, and pharmaceutical products worldwide.

The guarana plant is a monoecious species, with male and female flowers opening at different times (dichogamy) on the same plant (see Supplementary Material ESM1). Several studies have been conducted since the 1970s on the pollinators and floral biology of the guarana plant (Schultz and Valois 1974; Gondim 1978; Carranza et al. 1981; Erickson et al. 1984; Escobar et al. 1984; Ferreira 2003). The flowering period of P. cupana var. sorbilis varies yearly and appears to be related to rainfall patterns (Erickson et al. 1984; Escobar et al. 1984). Generally, the flowering period in the Amazon region begins in late July and ends in November when there is less rainfall.

There is a gap in observations on floral visitors between 2 a.m. (at the beginning of anthesis) and 6 a.m., the time when observations began in previous

Electronic supplementary material The online version of this article (doi:10.1007/s13592-014-0304-3) contains supplementary material, which is available to authorized users.

Corresponding author: C. Krug, cristiane.krug@embrapa.br Manuscript editor: Klaus Hartfelder studies by Schultz and Valois (1974), Gondim (1978), Escobar et al. (1984), and Ferreira (2003). According to these authors, the most effective pollinator species, based on flower observations, are the stingless bees of the genus Melipona. This preliminary study aims to answer two fundamental questions regarding the pollination ecology of $P$. cupana var. sorbilis as follows: (1) are there nocturnal/crepuscular flower visitors? and, if there are, (2) who are these visitors/pollinators?

To evaluate the occurrence of floral visitors from the beginning of anthesis, which begins at 2 a.m., surveys were conducted between 2 and 9 a.m. for 8 days, totaling $64 \mathrm{~h}$ of sampling. All the censuses/surveys were conducted on clear nights during all moon phases, on nonconsecutive days. Preliminary surveys to collect and identify nocturnal and crepuscular species were made in experimental and commercial fields of flowering guarana in the counties of Manaus (21 and 29/08/2011) and Maués (28 and 29/10/2011), respectively. Additional samples, to quantify (census) the nocturnal, crepuscular, and diurnal visitors, were collected in Manaus $(04,12$, 19 , and 26/09/2012). Sunrise occurred from 5:37 to 6:07 a.m. during the study.

Surveys were made every $30 \mathrm{~min}$ and each lasted 10 min. During each survey, the researcher walked slowly along the rows of guarana plants, counting the number of each type of bee (nocturnal, crepuscular, and diurnal) on the flowers in an area of 1 ha, which was surrounded by native vegetation. Due to easy recognition, the bee types were only counted as nocturnal (Megalopta spp.), crepuscular (Ptiloglossa sp.), or diurnal (all the other bees). Sampling was done using entomological nets. The flower visitors were observed and voucher specimens of the insects/bees were collected (authorization number 32357-1 MMA/ICMBio) and 
deposited in the Invertebrate Collection of the National Institute for Amazonian Research (INPA). The specimens were identified using the available literature and with the assistance of bee taxonomists.

At Manaus and Maués in 2011, a large number of nocturnal and crepuscular bees, belonging to the genera Megalopta spp. (Halictinae) and Ptiloglossa sp. (Colletinae), were observed visiting guarana flowers (see Supplementary Material ESM2 and ESM3). Bats did not visit the flowers during anthesis but some moths were seen resting on flowers and the vegetative parts of the plant, but did not collect nectar.

At Manaus, in 2012, bees were recorded as nocturnal, crepuscular, and diurnal visitors. Of the 1,333 bees recorded, $4 \%$ were nocturnal (observed between 3 and 5 a.m.), $8 \%$ were crepuscular (4 to 6 a.m.), and $88 \%$ were diurnal visitors (after 5.30 a.m.). The temperature was almost constant until six in the morning, which is when diurnal bees begin to actively fly; between five and six, the three types of bees were active: nocturnal (Megalopta spp.), crepuscular (Ptiloglossa sp.), and diurnal (Figure 1). The nocturnal bee visitors comprised four species: Megalopta aeneicollis Friese, 1926, Megalopta amoena (Spinola, 1853), Megalopta sodalis (Vachal, 1904), and Megalopta sp. The crepuscular visitors consisted of only one bee species, Ptiloglossa aff. lucernarum, whereas there were more than 20 species of diurnal bees, almost all of them stingless bees. In the phases of the full moon and the waning moon, the nocturnal and crepuscular bees were active an hour earlier, whereas diurnal bees did not change the starting time of their activities.

Megalopta and Ptiloglossa were observed visiting guarana flowers from 3.30 to $5.30 \mathrm{a} . \mathrm{m}$. and from 04.30 to 6.30 a.m., respectively. Both species actively collected nectar, but Megalopta showed a different behavior, moving slowly than Ptiloglossa in the flowers. Due to the behavior of the bees, pollen collection was not observed but this possibility was not discarded. Mating behavior was noted in $P$. aff. lucernarum during its activity on guarana flowers. Nests of these bees were not found inside or near the guarana fields and almost certainly these bees were nesting in the forest. Despite indications that both nocturnal and crepuscular bees can pollinate $P$. cupana, additional experiments are needed to clarify the role of these bees as effective pollinators.

Megalopta bees are strictly time constrained in their foraging behavior, flying only during two short periods, before sunrise and after sunset, possibly to explore rewarding pollen sources without competition and to minimize predation and nest parasites (Wcislo et al. 2004; Kelber et al. 2005). According to Smith et al. (2012), Megalopta bees in the tropical forest of Panama collected pollen from at least 64 plant species. Up to now, Megalopta and Ptiloglossa bees have not been mentioned as potential crop pollinators.

Garibaldi et al. (2013) described increased fruit set with flower-visitor richness, especially by wild insects,

\section{Bees visiting guarana flowers}

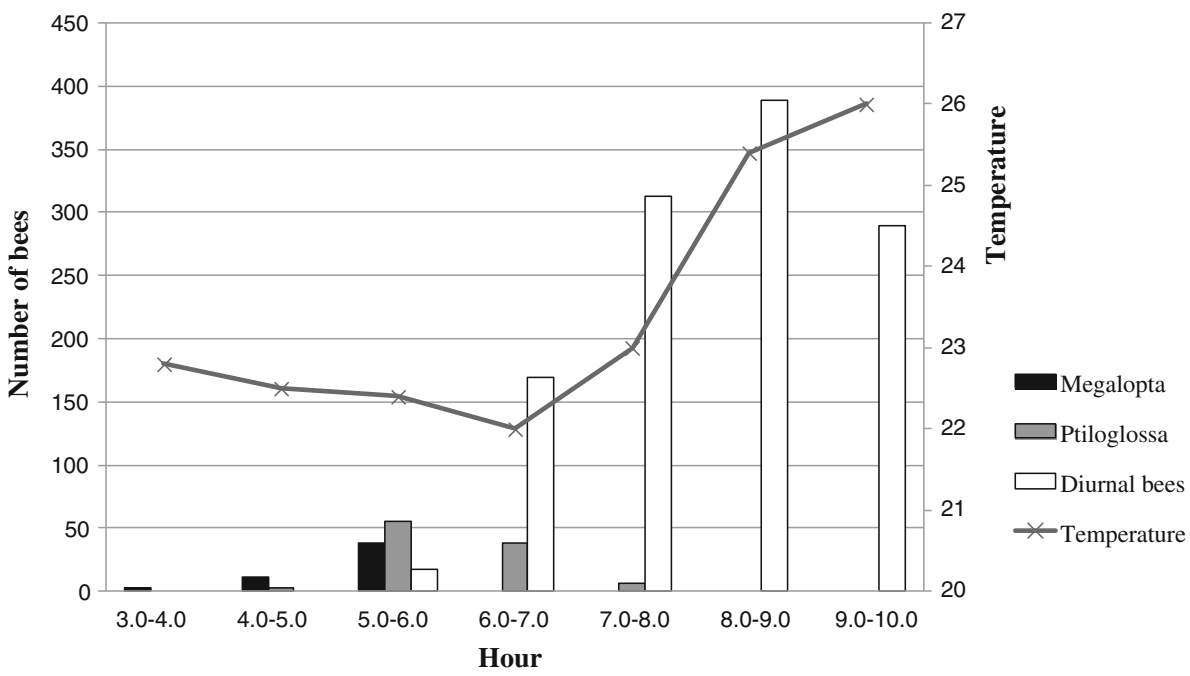

Figure 1. Number of bees visiting guarana (Paullinia cupana var. sorbilis) flowers per hour, mean temperature per hour during the survey days. 
from the results for multiple crop systems. This was also reported by Yamamoto et al. (2012) for passion fruit. The relationship of nocturnal and crepuscular bees with guarana flowers may be closer than simple flowervisitor richness, but this demonstrates the use of floral resource in different niches, where competition is low or absent.

More research is needed to clarify the pollination biology of the guarana plant, including identification of the effective pollinators and the contribution of bees to fruit set, specially nocturnal and crepuscular species. The guarana crop is a potential alternative for increasing the income of family agriculture and can be viewed as an opportunity to develop the Amazon region by associating the ecosystem service of pollination provided by the bee diversity and the forest with good farming practices.

\section{ACKNOWLEDGMENTS}

The authors thank Eduardo Almeida and Leandro Mattos Santos for identifying the bees.

Note scientifique: nouvelles perspectives dans la pollinisation du guarana (Paullinia cupana var. sorbilis)

Eine wissenschaftliche Notiz über neue Erkenntnisse bei der Bestäubung von Guarana (Paullinia cupana var. sorbilis)

\section{REFERENCES}

Angelo, P.C.S., Nunes-Silva, C.G., Brígido, M.M., Azevedo, J.S.N., Assunção, E.N., Sousa, A.R.B., Patricio, F.J.B., Rego, M.M., Peixoto, J.C.C., Oliveira, W.P., et al. (2008) Guarana (Paullinia cupana var. sorbilis), an anciently consumed stimulant from the Amazon rain forest: the seeded-fruit transcriptome. Plant Cell Rep 27, 117-124. Print

Carranza, R.E, Correa, M.P.F., Batista, M. de F. (1981) Técnicas para polinizações controladas em guaraná (Paullinia cupana var. sorbilis). Manaus: EMBRAPA-UEPAE Manaus. 3p. (EMBRAPA-UEPAE Manaus. Pesquisa em Andamento, 25).

Erickson, H.T., Corrêa, M.P.F., Escobar, J.R. (1984) Guarana (Paullinia cupana) as a commercial crop in Brazilian Amazonia. Econ. Bot. 38(3), 273-286

Escobar, J. R., Corrêa, M. P. F., Aguilera, F. J. P. (1984) Estruturas florais, floração e técnicas para a polinização controlada do guaranazeiro. In: Simpósio Brasileiro do Guaraná, 1., Manaus. Anais do I Simpósio Brasileiro do Guaraná, Manaus: EMBRAPA-UEPAE de Manaus. p. 240-256.

EMBRAPA (2005) A cultura do guaranazeiro no Amazonas, 4th edn. Embrapa Amazônia Ocidental, Manaus. 40

Ferreira, M. do N. (2003) Polinização dirigida em guaranazal cultivado utilizando-se abelhas Apis mellifera, Melipona seminigra abunensis e Scaptotrigona sp - Mato Grosso Brasil. 107 f. Tese (Doutorado em Ciências Biológicas) Universidade Federal do Paraná, Curitiba.

Garibaldi, L.A., Steffan-Dewenter, I., Winfree, R., Aizen, M.A., Bommarco, R., Cunningham, S.A., Kremen, C., Carvalheiro, L.G., Harder, L.D., Afik, O., et al. (2013) Wild pollinators enhance fruit set of crops regardless of honey-bee abundance. Science 339, 1608-1611

Gondim, C. J. E. (1978) Alguns aspectos da biologia reprodutiva do guaraná (Paullinia cupana var. sorbilis (Mart.) Ducke) Sapindaceae. 83 f. Tese (Mestrado) - Instituto Nacional de Pesquisas da Amazônia, Fundação Universidade do Amazonas, Manaus, 1978.

Kelber, A., Warrant, E.J., Pfaff, M., Wallen, R., Theobald, J.C., et al. (2005) Light intensity limits foraging activity in nocturnal and crepuscular bees. Behav. Ecol. 17, 63-72

Smith, A.R., Lópex Quintero, I.J., Moreno Patiño, J.E., Roubik, D.W., Wcislo, W.T. (2012) Pollen use by Megalopta sweat bees in relation to resource availability in a tropical forest. Ecol. Entomol. 37, 309-317

Schultz, Q., Valois, A.C.C. (1974) Estudos sobre o mecanismo de floração e frutificação do guaranazeiro. Manaus: IPEAAOc. p.35-58. (IPEAAOc. Boletim Tecnico, 004).

Wcislo, W.T., Arneson, L., Roesch, K., Gonzalez, V., Smith, A., Fernandez, H. (2004) The evolution of nocturnal behaviour in sweat bees, Megalopta genalis and M. ecuadoria (Hymenoptera: Halictidae): an escape from competitors and enemies? Biol. J. Linn. Soc. 83, 377-387

Yamamoto, M., Silva, C.I., Augusto, S.C., Barbosa, A.A.A., Oliveira, P.E. (2012) The role of bee diversity in pollination and fruit set of yellow passion fruit (Passiflora edulis forma flavicarpa, Passifloraceae) crop in Central Brazil. Apidologie 43, 51-62 